IdeAs

Idées d'Amériques

$7 \mid 2016$

Cinéma et histoire dans les Amériques

\title{
From "Plain Abe" to Mythical Mr. Lincoln. Constructing various representational modes of a screen icon
}

De « Abe le Commun » au mythique Monsieur Lincoln. Construction de modes de représentation d'une icône de l'écran

Del "Abe el sencillo" al mítico Sr. Lincoln. Construyendo modos de representación de un icono de la pantalla

\section{Anne-Marie Paquet-Deyris}

\section{OpenEdition}

Journals

Electronic version

URL: https://journals.openedition.org/ideas/1424

DOI: $10.4000 /$ ideas. 1424

ISSN: 1950-5701

\section{Publisher}

Institut des Amériques

\section{Electronic reference}

Anne-Marie Paquet-Deyris, "From "Plain Abe" to Mythical Mr. Lincoln. Constructing various

representational modes of a screen icon ", IdeAs [Online], 7| 2016, Online since 29 June 2016,

connection on 19 October 2022. URL: http://journals.openedition.org/ideas/1424 ; DOI: https://doi.org/ 10.4000/ideas. 1424

This text was automatically generated on 19 October 2022

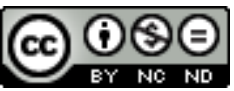

Creative Commons - Attribution-NonCommercial-NoDerivatives 4.0 International - CC BY-NC-ND 4.0 https://creativecommons.org/licenses/by-nc-nd/4.0/ 


\title{
From "Plain Abe" to Mythical Mr. Lincoln. Constructing various representational modes of a screen icon
}

\author{
De « Abe le Commun » au mythique Monsieur Lincoln. Construction de modes de \\ représentation d'une icône de l'écran \\ Del "Abe el sencillo" al mítico Sr. Lincoln. Construyendo modos de \\ representación de un icono de la pantalla
}

Anne-Marie Paquet-Deyris

\section{Introduction}

1 The first exercises in Lincoln screen iconography started in the early 1900s, most notably with the tableau shot at the close of Edwin Porter's 1903 Uncle Tom's Cabin produced by the Edison Film Company and representing Lincoln freeing a slave, and with Essanay Studios' 1908 The Life of Abraham Lincoln, a lost print likely to have been the first work featuring Abraham Lincoln's entire life. These early movies, quite a few of which were never retrieved, whether silent or talking, seem intent on representing the modes of construction of a historical giant. Their visual modes and grammar differ as do the aspects of Lincoln's legend underlined in the movies, from his Frontier-like tenacity in achieving his goals to his visionary capacity, but the aim seems to be constant, if not obsessional, to feature him as what David Donald calls the "ideal hero in classical mythology" ${ }^{1}$. To various extents, the filmic narratives all evince some hagiographic dimensions. This peculiar aspect is a potent source of fascination when analyzing the Lincoln-related films from the origins of cinema to the present time. Even Steven Spielberg's 2012 Lincoln, while portraying the scheming and devious actions of the president, eventually launches in the final coda into an ode to the Great 
Emancipator's extraordinary fight for the $13^{\text {th }}$ Amendment and the freedom of the slaves and his charismatic personality.

2 As the period of the Civil War receded further into the past, Lincoln's image seemed to become less salient in American life and cinema. The intense proximity between the American people and its sixteenth president seemed to stem from a number of essential reasons. When photography was invented in 1836, Lincoln quickly realized what great political impact it could have on electors. He started visiting photographic studios on a regular basis so that the general public could get acquainted with his distinctive face. These first attempts were consistent with the launch of the Lincoln Cent in 1909 for the first Lincoln $100^{\text {th }}$ anniversary. It further contributed to making available his slowlyconstructed image. Born at the end of the nineteenth century, cinema was to adopt quite naturally the different variations on Lincoln's image and adapt them to the needs of its new moving pictures. The interaction between these iconic agents and moments in American history was intensified by the close connection of the Lincoln persona with the Civil War period which also happened to be the first significant conflict ever to be documented in photographs in America. These different media seem to have somehow manufactured various modes of fascination with Lincoln. Historian Mark Reinhart underlines:

[Lincoln] was a natural subject for "moving pictures" since he had been such a memorable subject for "still pictures". Also, the same could be said for the Civil War itself. [...] Because the Civil War was such a crucial and dramatic period in American history, coupled with the fact that it had taken place only several decades before, it was perfect subject matter for the new entertainment industry. [...]

Lincoln had become a legend in the minds of many Americans. They viewed his life story as a personification of the American spirit, embodying the virtues of intelligence, compassion, resolve and love of country. (Reinhart, M., 1999: 7)

As irreversible shifts in the historical landscape of the United States, the Civil War and the birth of cinema thus provided a favorable backdrop for complex representations of Lincoln's figure. And because of the nature of the new medium, imagery, iconic postures and "props" started taking center stage, signaling the man's larger-than-life and highly symbolic dimension. Through the decades and up to World War II, Lincoln's literal canonization eventually bears little if any resemblance to the actual man. The trend strikingly intensifies starting with three central films, D. W. Griffith's 1930 Abraham Lincoln, John Ford's celebrated 1939 Young Mr. Lincoln and John Cromwell's 1940 Abe Lincoln in Illinois which already inscribe on screen a certain hagiographic and melodramatic vein which extends all the way to Timur Bekmambetov's 2012 Abraham Lincoln: Vampire Hunter.

Which adaptive strategies have the film directors used to shape Lincoln's figure over the years?

\section{Fanciful constructs and the displacement of "a man"}

Asserting the central position of this iconic figure in the filmic narrative and in the frame from the start seems to have been Griffith, Ford and Cromwell's main preoccupation. Yet the construction of the hero had already begun years before since, as Thompson and Reinhart show in their filmographies, many "Lincoln" films were produced in the first decades of the twentieth century. Ford for instance also made The Prisoner of Shark Island about Samuel Mudd, Lincoln's assassin's doctor, in 1936. In the 
1930s, the shaping of the leader's persona was still in full swing not only on screen, but also in the theatre. Abe Lincoln in Illinois starring Raymond Massey as Lincoln was actually a successful play on Broadway for which Robert Sherwood got the Pulitzer Prize for Drama in 1939 before turning it into a screenplay for John Cromwell in 1940.

What the directors seemed to be interested in was rather the variety of ideological processes of heroic construction at work than the production of some accurate historical pieces documenting Lincoln's "life and work". But why and how did such deliberately unsatisfying biographical sketches come to structure entire films?

Each movie actually starts with the literal or metaphorical birth of a man. In Griffith's first talkie, Abraham Lincoln, the artificial dimension of Lincoln's first appearance is staged in a highly melodramatic and expressionistic manner with the camera panning on a wintry landscape with bare desolate trees and a savagely howling wind and eventually focusing on the proverbial log cabin while the intertitle "February 12,1809" registers on screen. As it goes in to disclose the newborn, it then frames the exhausted face of the dying mother naming her son "Abraham" before a dissolve to an hourglass in close-up and a slightly low angle-shot. The hourglass shot foreshadows the mother's death and a new intertitle announces: "The story of a man begins". Because this highly stylized initial scene superimposes the birth and death motifs, it already categorizes the filmic narrative as belonging to the melodramatic rather than the strictly historical genre. And somehow, by contiguity, and by playing on the spectator's knowledge of Lincoln's fate, this programmatic opening sequence also inscribes the death of the hero even before he can actually be construed as a hero. The motherless boy who clears himself a path through the Wilderness and grows up against all odds to become a formidable leader draws pathos from the onset. In all three movies, the founding scene is the mother's death and the brief but potent references made to her fleeting presence and virtual haunting also inscribe the sense of predestination attached to Lincoln's persona. John Ford chooses to emphasize this eery dimension by focusing on an introductory intertitle characteristic of the silent era and quotes American poet Rosemary Benet's verse:

If Nancy Hanks

Came back as a ghost, seeking news

Of what she loved most,

She'd ask first

"Where's my son?

What's happened to Abe?

What's he done?"

“You wouldn't know

about my son?

Did he grow tall?

Did he have fun?

Did he learn to read?

Did he get to town?

Do you know his name?

Did he get on?"

9 By projecting the absent mother's questioning perspective into the filmic narrative, Ford introduces the spectator to his own version of the Lincoln genesis. Even though off-screen, Nancy Hanks' is a powerful emotionally-involved voice and hence functions 
as a model spectator asking the hermeneutic questions which will precipitate the narrative flow: "What's he done?", "Do you know his name?" The very formulation of the last question already signals the sacrificial, Christ-like dimension of her son's destiny and provides a framework for his future accomplishments. Somehow these programmatic lines already push Lincoln into manhood and maturity in the same way as he will be drawn by Destiny. As Tad Gallagher says in his analysis of John Ford's movies:

The myth of Lincoln also controls the character's freedom. The nineteenth-century theater had bequeathed an onerous tradition to Lincoln depictions, one that films had been thoroughly exploiting, too, and Ford capitalizes on the tendency of any Lincoln movie to be an apotheosis of its own genre, with conventional mythic elements and shorthand narration. As with his later cavalry epics, Ford's starting point is less actual historic fact than inherited myth, which he reinterprets via history ${ }^{2}$.

Actor Henry Fonda who had first turned down the Lincoln part eventually accepted it after viewing himself in full makeup in the test footage. He reportedly told an interviewer: "I felt as if I were interpreting Christ himself on film". The biblical echo of the last but one question, "Do you know his name?", harks back to David's words in Psalms, "And they that know thy Name will put their trust in thee: for thou, LORD, hast not forsaken them that seek thee" (Ps. 9:10). It also helps cast Lincoln in the role of the Great Defender, a virtually holy figure already heralding the greatest part he will be remembered for that of the Great Emancipator. Some characters, like the Clay women as their sons and husbands are charged with murder in the Ford adaptation, will indeed call out to Him and call his name when lost and in pain. In her insightful article, "The Image of Patriarchal Power in Young Mr. Lincoln (1939) and Ivan the Terrible, Part I (1945)", film analyst Marsha Kinder underlines the prophetic aspect of the mother's words:

Our identification with her perspective will soon be strengthened by the appearance of another maternal spectator in the text, Abigail Clay, whom Lincoln will explicitly identify with his own mother and who will play a similar spectatorial role in lovingly assessing her own two sons as well as the young Lincoln. [...] she's the one who poses the hermeneutic questions that control the narrative ("What's he done? ...Did he get on?") and which draw us into the spectatorial project of reconciling the two contradictory images of Lincoln that are familiar to us all: "plain Abe," her humble son, vs. "the Great Emancipator", whom she didn't live to see. [Kinder, 30]

11 It actually looks as if there were no escaping the mythologizing process when dealing with Lincoln's cinematic persona. The cunning, fiercely ambitious dimension of the character is glossed over, if not excised early on. Young commonfolk Lincoln is already half turned into a dream creature with the mystic and gloomy aura of the legend: Ford's preliminary narrative programme displaces humble Abe from the common ground of his extraction to relocate him in some alien dimension mainly signaled by the treatment of visual codes in the film. In each movie, physical stature becomes the index of Lincoln's power, even before Lincoln actually registers on screen. When Nancy Hanks asks, "Did he grow tall?" in the poetic prologue, she already successfully imposes the idea of growth-both physical and symbolical-as the nexus of any biographical sketch of Lincoln: How can a humble farm boy be turned into a historical giant? of course the question also has a definite metafilmic ring to it, since answering it has been every director's problem when working on a reconstruction of Abraham Lincoln's life 
and death. Kinder persuasively argues that the question was already at the heart of the original 1935 Howard Estabrook story outline which was never adapted for the screen:

He went from the bottom to the top. How did he do it? The answer is a timely parallel of a modern question more vital than ever now; how can the common man get ahead? We should maintain the underlining thread that carries the greatness of our theme, never losing the magic of the humble man who rises above the herd and then reaches down to help others. This is the punch that gives the picture "size" and conveys the feeling that we are in the presence of one of the great men of the world. (p. 1) The language in this passage (particularly the phrases I have underlined) clearly shows the valorizing of physical codes as a source of pleasure and success in the Hollywood industry's thinking. [Kinder, Note 8, 48)]

Each of the three filmmakers seems to deal with the question in a similar and ambiguous way. They all toy with the literal and figurative senses of "tall" and "great" so that Lincoln's size is both a source of embarrassment and a marker of his innate superiority. In John Cromwell's 1940 Abe Lincoln in Illinois, Raymond Massey, who was also playing Lincoln in the eponymous Broadway play at the time, is offered the opportunity to be the Whig party candidate for the Illinois state legislature. When a Whig official tells him, "You'll be associating with all the finest lawyers in this state. You'll grow!”, Lincoln playfully answers, “I thought I'd grown too much already!”.

\section{Framing a dehistoricized image}

D. W. Griffith also uses actor Walter Huston's height to the same effect in the sequence at the Springfield law firm when Lincoln is invited to be the presidential candidate. Slowly unwinding himself, Huston grows erect and towers above his interlocutors, thanking them in an awkward way before leaving for dinner and reaching a decision. The momentous gathering with the Republican politician and his associate who is looking up to him dissolves into the next iconic scene as it unfolds in a majestic lowangle shot. Lincoln, with his customary small-town lawyer "stove-pipe" top-hat on, is being led down the stairs by his two sons and the scene clearly inscribes the film's semiotic project: returning over and over again to the key sign of his greatness so as to validate his heroic dimension. This style of actual framing of the Lincoln figure is a recurrent motif in all three movies. The rapid shift from the domestic to the public sphere functions as a visual annoucement of the man's political stature-a phrase to be taken in its etymological sense of belonging to the city and the res publica. As the camera frames Lincoln in the staircase, it also materializes the head-on collision of the private and the public spheres. As the door opens onto the outside world, Lincoln's intimacy has already been compromised.

John Ford would remember this peculiar way of projecting an already mythologized image of Lincoln's on screen. In his silent 1924 masterpiece The Iron Horse, he had Lincoln support the construction of the first transcontinental railroad despite the builders' hardships and the CivilWar. He portrayed him as a unifier not only of North and South, but also East and West. In a celebrated echo in the course of his 1939 film Young Mr. Lincoln, he also pays homage to Griffith's mastery of visual codes and captures Lincoln in virtually the same position, facing the camera and an unseen crowd in a slightly low-angle shot, just before his transformation into a historical giant. With the double-framing effect achieved by a spectacular play on light and shadow, Lincoln suddenly-and literally-steps into the light. The boundary between intimacy and the 
public world is then forever erased. A door opens and the young lawyer's tall stature is illuminated. He is framed by a series of doorjambs capturing him poised on a symbolic threshold. As someone starts shouting, "the crowd's waiting!" and the cheering suddenly replaces the quasi-silence, Lincoln hesitantly takes off his hat and steps forward as if pulled by some invisible and irresistible force. Intent on capturing the exclusive birth of the hero, Ford never once focuses on the crowd. And the fact that is not shown already inscribes off screen a different public, no longer strictly from Springfield, Illinois, but from all over America.

In a 1970 well-known analysis of John Ford's Young Mr. Lincoln, the Cahiers du Cinéma editors $^{3}$ collectively underlined the fact that Ford's treatment of the Lincoln figure starting with his "eastern/western" The Iron Horse was turning it into some sort of universal referent usable in any particular historical situation. And precisely because Abraham Lincoln is this time the main protagonist of the filmic narrative, he can only be captured as being loosely connected to the historical context. Under the fifth heading of their essay, in the section called "Ford and Lincoln", the Cahiers editors specify:

As long as Lincoln appears in Ford's fiction as a myth, a figure of reference, a symbol of America, his intervention is natural, apparently in complete harmony with Ford's morality and ideology; the situation is different in a film like Young $\mathrm{Mr}$ Lincoln where he becomes the protagonist of the fiction. We will see that he can only be inscribed as a Fordian character at the expense of a number of distortions and reciprocal assaults (by him on the course of fiction and by fiction on his historical truth). ${ }^{4}$

Distortions of historical facts are then what John Ford, but also D. W. Griffith and John Cromwell alike, most play with. In this perspective, the treatment of Lincoln's political opinions and great discourses is characteristic of the reformulation of his historical persona. Virtually every purple-patch in the three movies is meant to redouble the actual effects Lincoln's speeches had on the audience, but not necessarily their exact circumstances and chronology. As Melvyn Stokes underlines, some of Lincoln's speeches, including the Lincoln-Douglas debates of 1858, are summarized in Griffith's 1930 biopic in a series of one-sentence exchanges ${ }^{5}$. Somehow, Lincoln's speeches provided the textual foundation of the myth which could forever expand precisely because they offered the kind of universal message reusable by Americans and other citizens alike throughout the ages and mostly in times of crisis. At the end of Abe Lincoln in Illinois, before leaving Springfield, Lincoln delivers his last speech in a melancholy, almost tragic tone. The scene actually foreshadows his universally known 1863 Gettysburg Address. The camera frames his weary face in close-up, already inscribing on screen his foreknowledge that he will some day join "those who here gave their lives that the nation might live". Cromwell also has Raymond Massey deliver this farewell address in the same awed and deafening silence as that which welcomed the President's two-minute speech at the Soldiers' National Cemetery on November $19^{\text {th }}$ 1863. His telling the crowd "I now leave not knowing when or whether ever I may return" and the recurrence of his gloomy line "And this too shall pass away" already function as the prophetic discursive and visual signs of his tragic ending. Though somewhat static, the camera alternates between medium close-ups of Lincoln speaking gravely, close-ups of individual electors listening intently and medium long shots of sections of the crowd looking up to him. Standing on the train platform as it slowly departs for Washington 
D.C. before the film's final fade-to-black, Lincoln is already captured in the final hieratic pose he will be most often represented in post-mortem.

Because Abe Lincoln in Illinois was a great success, by 1940 RKO Radio Pictures had become widely instrumental in "mythologizing" the presidential persona. One of Lincoln's military advisors, Edwin M. Stanton, allegedly said on the President's deathbed, "Now he belongs to the ages". The scene immortalizes Lincoln as a political and cinematic giant. As a serviceable figure, Lincoln was indeed to be constantly recycled in times of crisis to extol national unity so that the actual circumstances under which he did act as the Great Conciliator were eventually obscured and forgotten. Moviegoers of the Depression era used him for instance as an inspiration to surmount the economic hardships paralyzing the American economy at the time and above all as an icon of self-reliance, talent and compassion. Advertised as the perfect example of "Democracy in action," Frank Capra's 1939 Mr. Smith Goes to Washington makes explicit the connection between finding strength and inspiration in times of crisis and the Lincoln figure when the young idealistic senator played by James Stewart finds refuge in the Lincoln Memorial. Cromwell's own reconstructed figure seems to be the direct heir to "the Essential American" Walt Whitman paid homage to in his 1865 poem added as an appendix to Leaves of Grass:

o Captain! My Captain! rise up and hear the bells;

Rise up-for you the flag is flung-for you the bugle trills;

For you bouquets and ribbon'd wreaths-for you the shores a-crowding;

For you they call, the swaying mass, their eager faces turning;

Abe Lincoln in Illinois focuses more intently on the public speaker. Four speeches structure the film and design a hero slowly turning into a master of politics, from the backwoods of New Salem, Illinois, when Lincoln first runs for the state legislature, to Springfield on the night of his election to the Presidency. Somehow the image of the orator drives the filmic narrative which never stops chronicling what playwright Robert Sherwood and screenwriter Grover Jones call in an intertitle announcing a fast-paced montage sequence, the "years that marked the growth of a man, and of a nation". Lincoln is briefly framed delivering a speech at the State's Assembly. The spectator, however, cannot hear the speech, as if Lincoln's emblematic posture sufficiently inscribed on screen the powerful impact of his rhetoric, which hence increasingly distanciates him from any personal trajectory. By the end of the movie, as the statesman's stature and heroic legend grow, the private dimension is virtually erased.

In a seminal article on "The Lincoln Myth", Melvyn Stokes ties the birth of such a mythologizing process to the first biographical texts ever written on Abraham Lincoln:

The first major architects of the construction were John Nicolay, formerly Lincoln's secretary, and John Hay. The Century magazine published their biography of Lincoln over two and a half years at the end of the 1880s and, in 1890, with the serial ended, as a book in ten volumes (Nicolay and Hay). Not only was the Hay and Nicolay study of monumental size, it encapsulated a particular view of Lincoln as an ideal hero and semi-mythical character. ${ }^{6}$

21 What Nicolay and Hay seemed to have achieved, along with other biographers and hagiographers, is to root the process of mythic crystallization in authoritative and essential texts. Lincoln's secretaries initiated the construction process of the President's reputation and image, which was not yet taken as given in the 1860s and until the 1880 s. The fact that these first texts were actually published serially in a 
popular medium naturally helped disseminate them, but it also added to the public fascination for such a homegrown legend. Stokes quotes historian Eric Goldman who observes that "Lincoln, although the object [at the time of his death] of a great deal of immediate sentimentality, did not become the unassailable Abraham Lincoln of the schoolbooks until two decades after his murder"7. So that the competing and, at times, contradictory written versions of Lincoln's life fostered a manifold mythical and folkloric Lincoln. Yet Goldman barely seems to acknowledge the development of Lincoln as the merciful "Great Heart" who pardoned quite a few southern enemies or northern soldiers who fell asleep on their watches or deserted, especially in stage productions, and the emphasis on his democratic, western qualities as evoked at the end of the nineteenth century by William Herndon and Ida M. Tarbell. Building on Tarbell's early representation of Lincoln as the quintessential Westerner in her 1897 biography Abraham Lincoln, originally published as a series in McClure's Magazine, poet and historian Carl Sandburg chose to focus on Lincoln the man as a poetic, folkloric construct and to scrutinize his moral development as revealed by his acts and words. His two-volume biography, Abraham Lincoln. The Prairie Years (1926) and Abraham Lincoln: The War Years (1939), also contributed to removing Lincoln's figure from the flow of History. Whether such or such aspect of Lincoln is emphasized, it is always the result of a fictional graft process in which his figure ends up symbolizing quintessential American values such as generosity, reconciliation with America's "other" ethnic groups like Indians and African Americans.

Curiously enough however, although the figure seems to be plagued with some form of arrested (grand) development, these diverse Lincoln versions gave cinema leeway for endless variations. And it is precisely because he was both fascinated by and eager to be instrumental in the making of an American icon that Griffith wanted Sandburg to write the screenplay of his 1930 biopic. It was eventually adapted by another poet, Stephen Vincent Benét, for financial reasons. But Sandburg's canonical Lincoln constantly resurfaces on screen. In a similar trend, Cromwell's 1940 movie is loosely based on Robert Emmet Sherwood's Abe Lincoln in Illinois: A Play in Twelve Scenes (1937), another one of those preexisting grand narratives. In the foreword to his friend's play, it is also Sandburg who underlines the peculiar nature of such a combination of legend and drama, actual sources and a-historical reconstruction:

of natural, personal, human legends the one of Lincoln will probably last as long as any known-and the end of the world is a long time.

For many years, probably, many centuries, there are to be biographies about Lincoln-and dramas.

"Abe Lincoln in Illinois" by Robert E. Sherwood is the first full-statured drama that has come around the legend.

Also it is the first shaped by a playwright who went to the main studies derived from basic source materials-and delved extensively himself in the actual sources. The extent to which he realized his responsibility-in availing himself of a dramatist's license to depart from the facts-is soberly told in his supplementary notes. ${ }^{8}$

The hybrid nature of the literary source mirrors the mixed re-mediation of the cinematic treatment. Lincoln's figure is also used as an obvious mouthpiece and vector of the American Dream and the intersemiotic process of adaptation similarly involves some measure of freedom in creating the folk myth of indigenous greatness. As we saw, with Ford's 1924 The Iron Horse, the politician's figure had already been associated for 
quite some time with the moving - if not the talking pictures. The screenwriters and directors had consistently explored the man's heroic potential.

Congruent with the traits journalist Ida Tarbell drew on in her seminal biography published by McClure's magazine in instalments, most movies focused on the early life of the Western hero. The Westerner's peculiar background somehow provides the substratum necessary to the actualization of greatness and the aura of divine guidance surrounding the pioneer's figure cuts him off from the actual flow of History. Paradoxically, while linking him with central historical moments such as the coming into effect of Lincoln's Provisional Proclamation of Emancipation in January 1863 or the dedication of the cemetery at Gettysburg in November 1863, it also erases any clear connection to specific historical events in most films. The body of Lincoln Americana historian David Turley calls Lincolniana almost seems to function by itself, virtually independently of any clearly-marked period in the history of the Nation. It can thus be reinvested more easily in any filmic narrative. From D. W. Griffith's 1915 Birth of a Nation to Frank Capra's 1939 Mr. Smith Goes to Washington, fragments of Lincoln's actions and discourses are thus staged over and over in contexts having sometimes little to do with Lincoln's spirit and logic at the time. In Griffith's version for instance, the fact that a young soldier who fell asleep on the frontline is granted a presidential pardon operates more as the signal of Lincoln's innate generosity than as a historically accurate fact. This popularized side of Lincoln has actually been a traditional filmic trope since the earliest silent one-reel "Lincoln" films.

In Griffith, Ford and Cromwell's movies, it is mostly the treatment of the legend and the tone that differ, each fictional logic being constructed around a particular facet of the central mythic hero. Ford's Lincoln-Fonda walking up the hill toward his destiny against some stormy sky ${ }^{9}$ and the cut to the president's marble statue by Daniel Chester French at the Lincoln Memorial and Cromwell's portentous fade-to-black at the end both function as distinct visual and aural echoes of Griffith's melodramatic concluding sequence. The dark-hued tracking shot of Lincoln's log cabin dissolves into a series of majestic master shots of the very same Memorial. In all three films, the solemn bars of the Battle Hymn of the Republic both put an end to the filmic diegesis and call for the infinite space of myth to open up and constantly recycle and refine this grand narrative.

In most Lincoln movies until World War II, this carefully constructed glorious image actually defines Lincoln's big-screen portrayals for mainstream audiences. World War II propaganda movies would however modify the relation of history to filmic representation. Paradoxically, Lincoln's mythical figure then started being reformatted and its intensity began dwindling. Contemporary television broadcasts pick up where the movies' ideological projects and mythologizing constructions left off. So that the goal of programmes such as Harvard Professor Henry Louis Gates, Jr.'s 2009 Looking for Lincoln, is clearly to interpret evidence and to assess the validity of the Lincoln legend as the DVD jacket announces:

As Looking for Lincoln demonstrates, the Lincoln legend grew out of controversy, hurt feelings, greed, love, anger, clashing political perspectives, power struggles, and considerable disagreement over how our $16^{\text {th }}$ president should be remembered. "evok[ing] and mak[ing] meaningful the world of the past" ${ }^{10}$ have negotiated different "rules of engagement with the past"11. In the three movies of the corpus, they have 
demonstrated the persistence of Lincoln's cinematic persona as a stable point of reference through the changes in American society. Whatever aesthetic, generic and methodological choices the filmmakers have used to introduce the central character in the various filmic narratives, they seem to have only marginally reformatted his image, mainly concentrating on the major impact he had, and continues to have, on the production of American history. Whatever "the contradictions of our relationship to history-telling and the fantasy of history" ${ }^{12}$, Lincoln is invariably inscribed on screen as the Great Builder of the Nation.

\section{BIBLIOGRAPHY}

\section{Selected bibliography}

Donald, David, Lincoln Reconsidered, New York, Vintage, 1999.

Editors of Cahiers du Cinéma, "John Ford's Young Mr Lincoln [A collective text by the Editors of Cahiers du Cinéma]", translated by Helen Lackner and Diana Matias from Cahiers du Cinéma No 223, 1970, afterword by Peter Wollen, Screen, Vol. 13, No 3, Autumn 1972, p. 1-47.

Foner, Eric, The Fiery Trail: Abraham Lincoln and American Slavery, New York, Norton \& Co., 2010.

Gallagher, Tag, John Ford. The Man and his Films, Berkeley, Los Angeles, University of California Press, 1986.

Jackson, Martin A., “Abraham Lincoln”, in Peter C. Rollins (ed.), The Columbia Companion to American History on Film, New York, Columbia University Press, 2004, p. 175-179.

Kinder, Marsha, "The Image of Patriarchal Power in Young Mr. Lincoln (1939) and Ivan the Terrible, Part I (1945)", Film Quarterly v. 39, n² 2, Dec. 1985, p. 29-49.

Kunhardt III, Philip, Looking for Lincoln. The Making of an American Icon, New York, Knopf, 2008.

Reinhart, Mark, Abraham Lincoln on Screen. A Filmography, 1903-1998, Jefferson, North Carolina and London, McFarland, 1999.

Roman, Robert C., "Lincoln on the Screen", Films in Review, vol. 12, n² 2, February 1961, p. 87-101.

Rosenstone, Robert, History on Film. Film on History, London and New York, Routledge, 2012.

Slotkin, Richard, Gunfighter Nation. The Myth of the Frontier in Twentieth-Century America, Norman, The University of Oklahoma Press, 1998.

Schwartz, Barry, Abraham Lincoln in the Post-Heroic Era, Chicago and London, The University of Chicago Press, 2008.

Sherwood, Robert E., Abe Lincoln in Illinois, A Play in Twelve Scenes, With a Foreword by Carl Sandburg, New York and London, Charles Scribner's Sons, 1939.

Sipière, Dominique, "Vie, mort et renaissance du texte mythique : The Gettysburg Address au cinéma”, in Melvyn Stokes et Reynold Humphries (dir.), Cinéma et Mythes, Poitiers, La Licorne, 2003, p. 63-77. 
Stokes, Melvyn, “Abraham Lincoln and the Movies", American Nineteenth Century History, vol. 12, no. 2, June 2011, p. 203-31.

Stokes, Melvyn, “Abraham Lincoln”, in Melvyn Stokes, American History through Hollywood Film: From the Revolution to the 1960s, London, Bloomsbury, 2013, p. 55-86.

Sturken, Marita, "Reenactment, Fantasy, and the Paranoia of History. Oliver Stone's Docudramas", in History and Theory, vol. 36, n 4, Dec. 1997, p. 64-79, and in Spectator vol. 20, $n^{\circ} 1$, Fall 1999/Winter 2000, p. 23-38.

Thompson, Frank, Abraham Lincoln: Twentieth-Century Popular Portrayals, Lanham, Md, Taylor Trade Publishing, 1999.

Turley, David, “A Usable Life: Popular Representations of Abraham Lincoln”, in David Ellis (ed.), Imitating Art: Essays in Biography, London and Boulder, Co., Pluto Press, 1993.

\section{Filmography}

Cromwell, John, Lincoln in Illinois, 1940, DVD, Warner Home Video, USA, 2009.

Ford, John, Young Mr Lincoln, 1939, DVD, Warner Home Video, USA, 2009.

Gates, Jr., Henry Louis, Looking for Lincoln, DVD, Public Broadcasting Service Home Video, USA, 2009.

Griffith, D. W., Abraham Lincoln, 1930, DVD, Platinum Disc, USA, 2001.

\section{NOTES}

1. David Donald in Lincoln Reconsidered (New York: Vintage, 1999: p. 149), quoted by Melvyn Stokes (2011).

2. Tad Gallagher, John Ford. The Man and his Films, p. 164.

3. Editors of Cahiers du Cinéma, $\mathrm{N}^{\circ} 223$, Aug; 1970, pp. 29-47; translated in Screen, Vol. 13, $\mathrm{N}^{\circ} 3$, Autumn 1972, pp. 29-43.

4. Id., "John Ford's Young Mr Lincoln [A collective text by the Editors of Cahiers du Cinéma]", p. 13.

5. Melvyn Stokes, "Abraham Lincoln and the Movies," in American Nineteenth Century History, vol. 12, no. 2 (June 2011), 212.

6. Melvyn Stokes, “The Lincoln Myth", http://iris.ucl.ac.uk/iris/publication/104259/1, 14/02/2010.

7. Melvyn Stokes in “The Lincoln Myth", quoting Eric Goldman, The Tragedy of Lyndon Johnson, London, Macdonald, 1969, p. 13.

8. Carl Sandburg in « Foreword by Carl Sandburg » to Sherwood's Abe Lincoln in Illinois: xi.

9. Definitely a standard scene in Ford's movies as the director will reuse virtually the same sequence at the end of his 1940 adaptation of Steinbeck's The Grapes of Wrath, with Tom JoadHenry Fonda solemnly disappearing up a path in the distant chiaroscuro of the new dawn.

10. Robert Rosenstone, History on Film. Film on History, p. xi.

11. Ibid.

12. Marita Sturken, "Reenactment, Fantasy, and the Paranoia of History: Oliver Stone's Docudramas", p. 24. 


\section{ABSTRACTS}

The first exercises in Lincoln screen iconography started in the early 1900s, most notably with the tableau shot at the close of Edwin Porter's 1903 Uncle Tom's Cabin produced by the Edison Film Company and representing Lincoln freeing a slave, and with Essanay Studios' 1908 The Life of Abraham Lincoln, a lost print likely to have been the first work featuring Abraham Lincoln's entire life. These early movies, quite a few of which were never retrieved, whether silent or talking, seem intent on representing the modes of construction of a historical giant. As historian Mark Reinhart underlines "[Lincoln] was a natural subject for 'moving pictures' since he had been such a memorable subject for 'still pictures"'. How then is the Lincoln persona shaped in three central films, D. W. Griffith's 1930 Abraham Lincoln, John Ford's celebrated 1939 Young Mr. Lincoln and John Cromwell's 1940 Abe Lincoln in Illinois which inscribed on screen a certain hagiographic and melodramatic vein and had a long-lasting effect on the inscription of President Lincoln on screen? And how does the spectator relate to the directors' adaptive strategies and play on the certainty or ambiguity of the historical account?

Les premières inscriptions de Lincoln à l'écran commencent au début du 20ème, principalement avec La Case de l'Oncle Tom d'Edwin Porter sorti en 1903. Produit par Thomas Edison, il présente Lincoln libérant un esclave. En 1908, les studios Essanay produisent La Vie d'Abraham Lincoln, film depuis perdu qui, le premier, retrace l'intégralité de la vie de Lincoln. Ces films muets et parlants, disparus ou toujours visibles, mettent en scène les modes de construction d'un géant de l'Histoire. De quelle façon cette légende lincolnienne s'est-elle consolidée? Nous nous pencherons plus spécifiquement sur trois films qui ont marqué la représentation de la figure du président Lincoln, devenu un « sujet naturel » pour le cinéma, comme le souligne l'historien Mark Reinhart : Abraham Lincoln de D. W. Griffith sorti en 1930, Vers sa destinée (Young Mr. Lincoln) de John Ford de 1939 et Abraham Lincoln (Abe Lincoln in Illinois) de John Cromwell sorti en 1940 ont tous trois marqué l'histoire du cinéma et infléchi la représentation du président à l'écran en introduisant une veine hagiographique et mélodramatique. Comment le spectateur construit-il son propre rapport à l'histoire dans ces oeuvres entre greffe fictionnelle, vérisimilitude et approche parfois quasi-documentariste de la vie du 16ème président des Etats-Unis ?

Las primeras representaciones fílmicas de Lincoln se realizaron a principios del siglo XX, entre ellas se destaca La cabaña del Tío Tom de Edwin Porter (1903), producida por Edison Film Company, que representa a Lincoln liberando a un esclavo. En 1908, los estudios Essanay produjeron La Vida de Abraham Lincoln, esta película, que hoy se ha perdido, fue la primera, en seguir la vida entera del presidente. Estos filmes mudos o sonoros, perdidos o existentes, ponen en escena los modos de interpretar a un gigante de la historia. ¿Cómo se ha desarrollado la construcción del mito de Lincoln? Vamos a abordar más específicamente tres películas que han marcado la historia de la representación del decimosexto presidente de los Estados Unidos -que se ha convertido en un «tema natural» para el cine según el historiador Mark Reinhart-, Abraham Lincoln dirigida por D. W. Griffith (1930), la famosa Young Mr. Lincoln dirigida por John Ford (1939) y Abe Lincoln in Illinois de John Cromwell (1940). Esos tres filmes han configurado una tradición hagiográfica y melodramática. ¿Qué relaciones construye el espectador con estas obras que discurren entre recreaciones ficcionales, verosimilitud y a veces un enfoque casi documentalista sobre la vida de Lincoln? 
INDEX

Palabras claves: Lincoln, cinema, representación, historia, Estados Unidos

Mots-clés: Lincoln, film, représentation, histoire, Etats-Unis

Keywords: Lincoln, film, representation, history, United States

\section{AUTHOR}

\section{ANNE-MARIE PAQUET-DEYRIS}

Professeur d'études filmiques et sérielles anglophones, Université Paris Ouest, Dépt d'Anglais, 200 avenue de la République 92001 Nanterre Cedex, apaquet-deyris@u-paris10.fr 